\title{
CHALLENGES IN DELIVERING A BRAND PROMISE - FOCUSING ON MUNICIPAL HEALTHCARE ORGANISATIONS
}

\section{Purpose}

To investigate how healthcare professionals understand a new organisational brand and examine the ideas discussed in relation to it within health care organisations.

\section{Design/methodology/approach}

The research is based on a discursive approach that facilitates understanding how the informants perceived a new organisation brand and how that might shape their activities in the enterprise.

\section{Findings}

The study identified four distinct interpretative repertoires: the organisational brand as an economic solution, the magic wand, the factory, and a servant to the customer. The new brand was understood in terms of economic and business-like functions marked by external branding and its signs (logos etc.). The brand is not communicated to patients or colleagues, and the factory metaphor is applied to work practices. Hence, several potential dilemmas arise concerning the brand promise, customer expectations, economic and efficiency gains and the professional values of employees.

\section{Research limitations/implications}

Adoption of private-sector practices in semi-public or public-sector organisations is common. This study focuses on how private-sector ideas diffuse into the organisations and how they are translated within them.

\section{Practical implications}

We suggest a stronger emphasis on internal branding as a reconciliation to enhance legitimacy, highquality customer service and staff wellbeing. 


\section{Originality/value}

Theoretically, the unique contribution of the study is drawing upon health care branding, dilemma theory and discursive institutionalism in its interpretation. Consequently, it demonstrates how ideas about the brand and public health care are translated and communicated in the examined discourses and how those ideas reconstruct understanding and change behaviour within the organisations.

Keywords: Branding, dilemma theory, discursive institutionalism, public organisation, health care organisation, discourse analysis

\section{Introduction}

For several decades the Nordic welfare model has been central to the success of the small Nordic economies, and the right to healthcare based on citizenship has been one of its cornerstones. However, the welfare model is under intense pressure (Forsander, 2004; Johansson and Hvinden, 2007; Wahl, 2007) as the economic and human resources available to public-sector organisations diminish even as challenges mount. Finland's public-healthcare sector, for example, is struggling to maintain high-quality service provision and is introducing multiple structural and organisational reforms.

As a consequence, healthcare is increasingly being privatised. The flow of new ideas, translations of them and further adoption of private-sector practices in the search for legitimacy (Colyvas and Powell, 2006; Deephouse, 1996; Suchman, 1995; Schmidt 2006; Czarniawska \& Sévon 1996) and efficiency (Pollit and Bouckaert, 2011) started a few decades ago. One example of such practices is organisational branding. This is considered important because successful brand management can enhance the attractiveness of an organisation as an employer in the eyes of the personnel, whereas unsuccessful branding may have the opposite effect. New private and semi-private organisations seek to differentiate themselves from competitors, achieve efficiency, secure funding, recruit and retain quality employees and attract customers. However, branding is not under the sole control of management, and serviceorganisation employees should identify with and commit to the brand (e.g., Punjaisri and Wilson, 2011). 
Organisational branding in the context of these new private or semi-private healthcare organisations has not been widely researched, despite the clear evidence from other management areas of difficulties in trying to adopt private-sector practices (Kallio and Kuoppakangas, 2013). We argue that there is limited understanding of how employees in these new organisations understand and commit to branding and the specific dilemmas linked with it. Our aim is to address this issue, and investigate how healthcare professionals in three healthcare organisations understand the new organisational brand and the related practices, and the extent to which the dilemmas that arise are connected to their understanding and interpretative repertoires. The study relies on a discourse analysis of interviews with managers and employees in healthcare organisations.

On the theoretical level we build upon the existing literature on public branding (e.g., Chapleo, 2010, 2013; Suomi, Lemmetyinen and Go, 2013). Although the case organisations have undergone a transformation into an organisational form resembling a semi-private business, the municipal enterprise, they are still owned by public-sector municipalities and are responsible for producing public services. Moreover, because of broad organisational reforms in our case organisations, we also consult recent academic literature on rebranding (Miller, Merrilees \& Yakimova 2014) to refer to rebranding of the Finnish healthcare sector.

We utilise dilemma theory (Hampden-Turner, 1981, 1990, 2009; Kuoppakangas, 2014) and refer to the literature on internal branding as a potential means of reconciliation (e.g., Punjaisri and Wilson, 2007, 2011). The contribution of this paper is twofold. First, it investigates the organisational and institutionalised ideas of branding / marketing activities from the perspective of employees. Second in identifying the dilemmas and offering reconciliation it contributes to the literature on the role of publicsector healthcare branding in safeguarding the competiveness of healthcare organisations.

\section{The theoretical framework}

Branding in a public-sector context 
The American Marketing Association (1960) described branding in terms of a 'name, term, sign, symbol or design.... intended to identify or differentiate goods or services from those of competitors'. This definition subsequently evolved to embrace certain emotional dimensions, and more contemporary definitions refer to brands imbued with 'their own qualities and characteristics that can provide emotional and self-expressive benefits to the consumer' (Stride and Lee, 2007). Branding follows the marketing concept in expanding to sectors away from its product roots (Kotler and Levy, 1969), to the wider non-profit community (Stride and Lee, 2007) and public-sector organisations (Wæraas, 2008).

Branding may have value for the public sector: good brands are central to generating and sustaining competitive advantage, and brand management is a basic organisational competence to be understood and developed (Aaker, 1996; Louro and Cunha, 2001). In practice, many public organisations are increasingly managed as organisational brands (Kotler and Kotler, 1998; Whelan and Wohlfeil, 2006). This move towards branding has largely come about through necessity, driven by factors such as increased competition, a focus on differentiation and increasing 'marketisation' (Becher and Trowler, 2001; Kotler and Kotler, 1998). However, some public organisations have a long way to go in terms of incorporating the branding concept and only limited progress has been made in developing practices and infrastructure that support effective branding.

However, private and public organisations are not identical. The latter have several functions that may require inconsistent values, struggle to find concise identity definitions (Wæraas, 2008), are arguably more complex, and find it difficult to commit their internal stakeholders to branding concepts (Hankinson, 2001, p. 231; Schultz and Barnes, 1999). The reticence to fully embrace branding may be attributable to the continuing debate on the desirability of marketing practices within public organisations (Jevons, 2006). The benefits of branding are challenging to quantify in any sector, but particularly so that concerning public services. Commercial models do not wholly suit organisations in which metrics such as market share, price premium, and loyalty were traditionally alien.

Branding in public organisations may create a spirit of unhealthy competition, prompting expenditure that is of dubious benefit (Sargeant, 2005). However, Blumenthal and Bergstrom (2003) suggest that it 
can offer something of substance to help stakeholders differentiate between organisations. Brands may be both a strategic asset and a source of sustainable competitive advantage (Caldwell and Coshall, 2002). If they make the consumer's choice process more effective (Doyle, 1989), this alone could constitute a strong argument for promoting branding in the public sector.

Good branding must be able to embrace the complex stakeholder environment of public organisations. Marketing inevitably invades most areas of the organisation, and consequently marketing people will run up against internal stakeholders with strongly held views (Low and Fullerton, 1994). Cultural resistance to the ethos and practice of branding is therefore an issue for public organisations in which underpinning marketing philosophies may be theoretically uncomfortable (Brookes, 2003), and it may be difficult to commit internal stakeholders to branding concepts (Hankinson, 2001). The cultural context also influences how staff members implement brand values through social processes (Vallaster and de Chernatony, 2005). Organisational values may be a source of competitive advantage but only if the brand values are respectful of those values and embrace them (Hatch and Schultz, 2003).

\section{Healthcare branding}

Research on health care branding focuses largely on commercial health care providers (Kemp, Jillapalli \& Becerra, 2014; Gapp \& Merrilees, 2006) and therefore is conceptually embedded in the service branding literature (Kemp, Jillapalli \& Becerra, 2014) rather than that relating to non-profit / public sector branding. Few studies focus on public sector healthcare branding (Hudson, 2009).

There are, however, inherent qualities common to all healthcare branding; as a sector it is a highly intimate and personalised service and therefore requires a solid organisational approach to deliver a unique standard of consistency (Kemp, Jillapalli \& Becerra, 2014). All healthcare providers need to deliver the type of care required and communicate that, whether to end users, regulatory authorities or other stakeholders; a strong brand in healthcare can do this as it has the capacity to connect with people's emotions (Berry, 2000). The specific advantages of branding in public sector healthcare concern winning loyalty and competing effectively, in a time of increasing free choice in markets 
(Hudson, 2009). It is acknowledged, however, that there remain significant challenges in terms of internal organisational values even when the benefits can be clearly articulated.

\section{Internal and external branding}

Organisational branding has long been a necessity for private-sector firms, and has been widely studied by marketing and management scholars (e.g., Aaker, 1996, Aaker \& Joachimsthaler, 2002; Aurand et al., 2005; de Chernatony, 1999). Brand building and communication focusing on external stakeholders (e.g., de Chernatony \& Harris, 2000), and tangible elements such as names, logos, slogans, colours and other visible elements (e.g., de Chernatony \& Dall'Olmo Riley, 1997) are, however, only part of a successful brand-building process. We refer to this approach to branding later in this article as external branding (Davies, 2008; Vallaster \& de Chernatony, 2006), the aim of which is to form a package that represents a compelling 'purchase value proposition' to prospective and current customers (Simmons, 2009, pp. 686-687). In addition, as stated in the previous section, managers should pay attention to employee engagement and internal branding (e.g., Punjaisri \& Wilson, 2007; Aurand et al., 2005). This study relies on the definition of internal branding provided by Punjaisri et al. (2009, p. 567): 'The use of internal communication techniques and training programmes to educate employees about the brand promise'. Successful branding is understood as the alignment of external and internal efforts (see e.g., Simmons, 2009).

Internal branding has prompted far less research than external branding (Devasagayam, Buff, Aurand, \& Judson, 2010), which is surprising given its growing importance. A brand's identity should be consistent with employee values and behaviour (Harris \& de Chernatony, 2001), and internal brand building is integral to developing a successful brand (Vallaster \& de Chernatony, 2006). Miller et al. (2014) suggest that internal branding encourages both employees and managers to support a new branding strategy. This includes not only behaviour but also commitment to and understanding of the brand. Some use the terms internal branding and employer branding synonymously (Aurand et al., 2005) to describe branding with a special focus on internal constituencies, particularly employees (Foster, Punjaisri, \& Cheng, 2010). Foster et al. (2010), however, distinguish between the two, suggesting that internal 
branding has an internal focus (i.e., current employees), whereas employer branding pinpoints the external constituents, namely potential employees. Our focus here is on the former, but we acknowledge that internal branding is closely related to employer branding (see e.g., Aurand et al., 2005).

Contemporary public-sector organisations increasingly face the same challenges as private-sector firms. They are expected, for example, to differentiate themselves from competitors, to pursue efficiency, secure funding, recruit and retain high-quality employees and attract customers. Given the increasingly tough competition among public and non-profit organisations, brand building will inevitably simultaneously assume greater significance in the sector (e.g., Stride \& Lee, 2007). Despite increasing research on branding in public-sector organisations (e.g., Chapleo, 2013; Wæraas, 2008; Wæraas \& Solbakk, 2009), few investigations concentrate on internal branding, particularly in healthcare as the present study does. An exception is Gapp and Merrilees's (2006) study focusing on internal branding in a major healthcare organisation in Australia involving both public and private hospitals.

Insufficient understanding of branding may lead to a situation in which a brand is communicated only to external stakeholders, particularly customers, and employees do not fully identify with it or commit to it (e.g., Punjaisri \& Wilson, 2011) also described as living the brand (Ind, 2001). That particularly affects service organisations because 'service employees are often considered the embodiment of the service brand in the consumers' eyes' (Punjaisri, Wilson, \& Evanschitzky, 2009a: 561; see also Simmons, 2009), and influence stakeholders in various service encounters (Punjaisri, Wilson, \& Evanschitzky, 2008). Internal branding has a positive impact on employees' brand identification, brand commitment and brand loyalty (Punjaisri et al., 2009a; Punjaisri, Evanschitzky, Wilson, 2009b), and according to Miles and Mangold (2005) forms a psychological contract between an employee and an organisation that goes far beyond the employment contract. Furthermore, Vallaster and de Chernatony (2006) strongly emphasise leadership and the example a manager sets in legitimating the importance of service delivery to employees. Miller et al. (2014) consider internal branding activities to relate to encouraging stakeholders to buy into the new brand as well as to ensuring the continuity of brand elements.

\section{The dilemma approach}


Branding (both internal and external) requires on-going decisions in terms of desired brand values, positioning, messages, and prioritising stakeholders, for example. These decisions may necessitate a greater degree of compromise in public-sector organisations than in private companies owing to the challenges discussed above. However, in any decision-making process there is rarely one optimal, correct response (Kuoppakangas, 2014). The dilemma approach therefore seems to offer a framework for identifying extremes in any decision dilemma (e.g., the optimum brand position on any two opposite variables) through recognising the organisation's position in relation to those extremes (when compromise may be detrimental to both). The question is whether optimum brand-strategy practice falls closer to the middle or to either extreme: it is not simply a matter of looking for that elusive point of balance in brand management, but it is rather a both-and reconciliation process aiming at synergy of the two extremes. In this the dilemma approach could offer insights and a workable model of public branding.

Dilemmas are considered a prevailing phenomenon in the current literature on organisational studies and the public sector (Pollit and Bouckaert, 2011; Smith and Lewis, 2011; Storey and Salaman, 2009). However, the discussion tends not to go further into how the dilemmas are generated and how they might be reconciled. Furthermore, the theoretical discussion appears to be rather scattered and unfocused, the emphasis in much of the literature apparently being on avoidance (Quinn, 1988; see also Handy, 1994). By way of an exception, Hampden-Turner (2009) suggests that cherishing rather than avoiding dilemmas may be more fruitful, and may foster new, innovative solutions in organisationaldevelopment schemes (Figure 1).

Figure 1. The reconciliation of dilemmas (adapted from Hampden-Turner and Trompenaars, 2000, p. 355; Hampden-Turner, 2009, pp. 107-127 see also Kuoppakangas 2014)

Thus, as Hampden-Turner (2009) points out, strategic dilemma management and reconciliation is an ongoing process that is helical in structure, hence the core task is to find the best solution at the time and then to prepare for the next dilemma (Figure 1). This gives us good reason to adopt Hampden-Turner's $(1981,1990,2009)$ dilemma theory in this study given its methodological acceptance of the fact that 
dilemmas exist in economic and organisational contexts, and that such dilemmas may be reconciled and used strategically to strengthen an organisation's competitiveness.

\section{Data collection and analysis}

Finland is a Nordic welfare state, and thus a relevant research context on the subject of marketing in the public-healthcare sector undergoing a privatisation-type transformation. The qualitative case research for the study was carried out in Finland in 2007 and 2011. The three case organisations, UlabA, UlabB and UlabC, are Finnish publicly-owned university-hospital clinical laboratories. All three went through similar organisational processes of transformation to become municipal enterprises from their former balance-sheet-oriented form in the late 1990s (UlabC) and in 2004 (UlabA and UlabB). Their combined annual turnover at the time of the data collection was approximately EUR 30 million, and they employed close to 2,500 people.

The criterion for inclusion was that the organisation had to be a municipal enterprise. The first, UlabC, was chosen because it had recently become one. The CEO was the first to be interviewed, and the snowball method was used to find new informants and new case organisations. All the informants at UlabC mentioned UlabB and UlabA, which were therefore chosen as further cases. The interviews were thematic in nature.

A total of 20 informants (five from each case organisation and five experts on the legal and economic aspects of becoming a municipal enterprise) were interviewed. Given the uncertain future of this form, another four informants were interviewed in 2011 to acquire current information on the relevant legal issues. All the interviews were transcribed and content-analysed in five phases. Moreover, the researchers had access to secondary data that enabled them to develop a thorough understanding of the case organisations and their contexts, and supported the interpretations based on the primary data (Shank, 2002; Silverman, 2000; Yin, 2003).

\section{Discourse analysis}


Discourse analysis is a loose methodological framework rather than a single method (Grant et al., 2004). The focus is on language, and how it creates social reality. Language gives meaning and simultaneously constructs, reproduces, and transforms the social reality in which we live (Jokinen et al., 1999; Grant et al., 2004). Discourses are a two-way relationship: the discursive event shapes and is shaped by institutions, structures, and situations. Discourses are constitutive both in maintaining the status quo and also in transforming it. The analysis potentially shows how discourse is central to the social construction of reality, and how, via a variety of discursive interactions and practices, it goes on to shape and influence people's attitudes and behaviour. Consequently, discourse analysis may shed light on the meanings managers and professionals assign to the organisational transformation into a municipal enterprise from the former public-sector organisation, and to the new organisational brand. Our interest is in how people use different and conflicting discourses to understand the world around them or to achieve certain goals (Eriksson and Kovalainen, 2008).

Moreover, the three case organisations of this study are representatives of professional bureaucracy and of institutions (Scott, 1996; Tevameri, 2014; Mintzberg, 1979). Furthermore, as organisations they are greatly dependent on and influenced by healthcare professionals and public policies and have therefore been labelled institutionalised organisations (Mayer \& Rowan, 1977; Scott, 1983b, pp. 102; see also Peters, 2012). According to Schmidt (2006) in the discursive institutional approach, institutions are defined by ideas and how they are communicated through discourses and discursive interaction. Ideas are central to change and may constitute new institutions, in other words, change but also continuity. In the discursive institutional approach, ideas constitute discourses which aid the (re)construction of actors' understanding of issues like change and help to redirect their actions within the institutions involved. Discourses are sets of ideas that may introduce new values, rules and practices and legitimate those ideas (Schmidt, 2006; Peters, 2012, pp 112-126).

The discursive approach adopted in this study reveals how the participants understood the new organisational brand (Potter and Wetherell, 1987), and how that might have shaped their activities in the enterprise. Accordingly, the aim is not to generalise from the results. The approach relies on sociopsychological discourse analysis, the aim of which is to identify interpretive repertoires. 
Analysis

The analysis began by transcribing the recorded interviews and one of the authors [1] reading the texts to identify the sections in which the participants talked about the municipal enterprise form: the motives and reasons and the outcomes. These sections were discourse-analysed, focusing on the following issues (e.g., Eriksson and Kovalainen, 2008):

- What kind of conflicting ideas and tensions could be elicited from the texts?

- What consequences or requirements could be constructed for the new organisational brand?

The aim was to identify how the healthcare professionals understood the municipal enterprise, what kind of ideas they had formed about the new municipal enterprise as a brand, and how those ideas influenced their actions in this new public health care organisation representing a new or emerging institution (Schmidt, 2006). It is important to underline that we did not attempt to isolate or compare the views of individuals, or to compare the accounts between different individuals or organisations, but rather sought to generate knowledge about the meanings that could be attached to the municipal enterprise organisational form - the new organisational brand. The analysis and identification of interpretative resources is an iterative interpretive-analytical process of reading, re-reading, and coding interviews as categories of discourse and practices emerge, to be further considered in relation to each other (see Golden and Geisler, 2007). We identified four interpretative repertoires: The municipal enterprise as an economic solution; the municipal enterprise as a magic wand; the municipal enterprise as a factory; and the municipal enterprise as a servant of the customer.

\section{Findings: Interpretative repertoires of the municipal enterprise as new brand}

The repertoires, the discursive moves they represent, the specific practices the moves were associated with, and what they accomplished with regard to the brand are discussed in this section and summarised in Table 1.

Table 1. Interpretative repertoires of the organisational brand and associated discursive moves, practices and consequences 


\section{The municipal enterprise as an economic solution}

The discursive repertoire of understanding the new organisational brand from the economic perspective becomes evident in the analysis. The idea of needing to be more business-like in operations is a recurrent theme, and this is closely related to money, funding and economic efficiency. Maintaining a low price for and streamlining service processes, achieving efficiency and flexibility in decisionmaking, enhancing market-oriented capability, and addressing resistance to change are also emphasised.

The municipal enterprise as an organisational form is constructed as a tool for promoting professional leadership by having a CEO and separate budgets and profit and loss statements, and with the idea of self-funding its activities. The participants distinguished between the past and the present where the municipal enterprise was capable of doing more.

.... and the core idea of the municipal enterprise is to be run by individuals who are responsible for the finances...I think it's the economics, it's easier to operate as a municipal enterprise when you can remove the overlaps. (H10)

Conversely, the participants expressed the idea that only by being a separate municipal enterprise could they achieve financial gains.

We do budgeting, we follow [the costs], we conduct tenders, we have sort of caught up with the idea of the municipal enterprise and those hard facts... we have lowered prices too. (H3)

The municipal enterprise as a new organisational form inspired considerable discussion of costeffectiveness, and of developing the organisational structures to deliver greater efficiency in healthcare. The issue of transparency also arose in terms of putting a price tag on healthcare services visible to all stakeholders.

Well, does it make sense to have your own money? If we know that for this price we can sell the products and it's a good business, this is the main issue in the municipal enterprise and we could then expand our activities. (H3) 
Despite these positive repertoires the healthcare professionals found it difficult to construct ideas that combined economics and care, and the lack of a customer/patient focus became visible in the analysis.

\section{The municipal enterprise as a magic wand}

The second repertoire concerned the municipal enterprise as an entity coming into existence through signs of external branding such as logos, advertising slogans, colours, and fonts. The new organisational brand was seen as a trend:

These organisational models come into fashion, and why not use them. As this change was made in [other laboratory] it was a good stimulus for us to do it as well. (H14)

The organisational brand was understood as a way of developing an external brand for the organisation. Here the emphasis was on how the organisation looked from the outside, and how the brand - acting like a magic wand - would make it better.

This is some kind of branding, that the $[\ldots]$ hospital district organisation is doing, this transformation into a municipal enterprise! (H11)

In this repertoire new websites and other marketing materials were portrayed as signs of the new municipal enterprise.

Have you seen our home page? It looks nice. The advertising company tells me that the content has to be updated frequently. But who has the time to do that? (H3)

Through these artefacts the participants made sense of and constructed the new organisation, and expressed their pride:

Our annual report has a very professional look, it's produced on high-quality paper, as you can see. It's very informative and our high-tech processes are well presented. (H10)

In this repertoire the municipal enterprise acquires a special status or a symbolic and almost mystical role: 'I don't know what is in this municipal enterprise form, but it seems like a magic wand'. (H4) 
In this repertoire the magic wand can be viewed as a positive trigger for change but it can lead to disillusionment.

One thing I can say is that this is not a magic wand - but it does somehow give a more business-like status to a public-sector organisation. Nevertheless, I can't see how just an organisational form can increase efficiency. I have to say I have seen quite the opposite happen with these quasi-market public organisations. (H8)

\section{The municipal enterprise as a factory}

In the third repertoire work in the new municipal enterprise was discussed using the metaphor of a factory. This repertoire spoke of the confusion surrounding the adoption of a municipal enterprise organisational form and the sense of unease with the outcomes.

Really I don't know what has changed [...] or what brought the change about. I'm not sure if it was the municipal enterprise form that did it, or the management $[\ldots]$ I mean the new efficient factory-type laboratory processes. (H17)

Overall, there was a strong sense of confusion and uncertainty surrounding the idea of the municipal enterprise.

...we had some kind of briefing where the municipal enterprise form was explained to us, but I don't know how much we understood about the real change from before. (H12)

The job titles adopted also reflect the ideas of a factory (the former department nurses are called supervisors) with the underlying promise of improved remuneration.

The argument that it would be easier and there would be an opportunity to give the employees better pay and to introduce a bonus system; that was an outrageous lie; there was no truth in it. This is causing a lot of bad feeling and it will never be healed.

Ah well, to me all this seems very hypocritical. It may look good on the outside, but if promises made to the employees are not kept... (H11) 
The idea of the municipal enterprise is also constructed by resorting to a new vocabulary reminiscent of the factory: 'We talk all the time about outputs, work inputs, numbers...' (H16). Equally, it is reinforced by constructing efficiency as the antithesis of good patient care:

If we advertise that we give high-quality care, but don't have the time to do so, which we did have before the organisational change, there's a big question mark. (H16)

The municipal enterprise as a servant of the customer

The adoption of the municipal enterprise was emphasised in relation to the high quality of laboratory diagnostics as well as the speedy delivery. 'We have top quality, we are reliable, and our expertise receives the highest praise in our customer surveys' (H11). In this repertoire the successful lowering of the laboratory-service prices was also portrayed as a positive outcome of the municipal enterprise transformation.

Despite these positive outcomes for the corporate customers the individual patients were construed as victims of the change. 'We have these long waiting-room benches on which the customers sit so we have forgotten the customer a little bit'. (H16)

The lack of money and time for patient care were construed as a challenge to the institutionalised ideas of professional values held by healthcare professionals:

When we think about professionalism, you don't want to hear about being able to afford it when professionalism is about taking care of patients'. (H3)

\section{The interpretative repertoires and their consequences}

The interpretative repertoires identified in the analysis seem to point towards multiple dilemmas that healthcare professionals and their organisations must tackle. On the one hand the strong focus on financial gains and efficiency seemed to override any other goals in the adoption of the new organisational brand and the municipal enterprise organisational form. In particular, the employees 
constructed an idea that the patients had been forgotten in this process: the time allocated to them at the laboratories had been reduced so as to cut costs, leaving patients' questions unanswered and them feeling insecure.

Table 2. Dilemmas identified in the analysis of interpretative repertoires

The strong focus on finance, budgets, and resources and also the implementation of streamlined factorytype processes seem at odds with the core values of healthcare - high-quality patient care, empathy and humanity - leading the professionals to feel they are failing to deliver their brand promise to the customers due to time constraints and the need to cut costs (Table 2).

The strong economic and efficiency focus may also affect the brand promise, and thereby disappoint patients and healthcare professionals alike. An undelivered brand promise could be considered a failure in that it means not meeting customer expectations. Apparently, the informants are uneasy and confused about the new marketing orientation, and in particular about the municipal enterprise as a new organisational form and the organisational brand (Table 2).

\section{Discussion}

Public-sector organisations are entering new private or quasi-private markets on various levels. They need to respond to competitive pressures similar to those private organisations face, thus brand building has assumed greater significance in public healthcare but received limited attention in research, and the perspective of employees has certainly been neglected. This study aims to address that knowledge gap and contribute to research on how employees interpret public-sector and healthcare branding. It examined how healthcare professionals in three case organisations talked about the adoption of a new organisational brand, how that shaped their understanding of the new organisation and their own work within it, and how the dilemmas that arose related to their interpretative repertoires. The findings are based on a discourse analysis of interviews conducted with managers and employees in these healthcare organisations. 
Business-type tools and activities are increasingly applied in public sector organisations. According to the notion of discursive institutionalism (Schmidt 2008), ideas flow into organisations from the external organisational environment and branding is a good example of such a diffusion of ideas. Depending how those ideas are discussed and understood will bear an effect on how the new ideas are accepted and translated into the organisation, and if they will imply changes (Czarniawska \& Sévon 1996; Bonnedahl \& Jensen 2007). Due to the inherent differences between the public and private sectors, the adoption of private-sector ideas may create dilemmas in public organisations (Thynne \& Peters 2015; 2015; Lane 2009).

The current research has identified four distinct interpretative repertoires: the organisational brand as 1) an economic solution, 2) a magic wand, 3) a factory, and 4) a servant of the customer. The new brand was understood to strongly reflect the desire for more business-like actions in the three organisations. Being more business-like was associated with economic efficiency, cost savings and accountability. The new organisational brand led by a CEO and accompanied by more autonomous decision-making was considered a change for the better.

However, the adoption of a new organisational brand as a municipal enterprise was challenging for employees in several respects. The existence of external branding with its clear signs and symbols to external stakeholders was acknowledged, but the infomants had mixed feelings about the essence of the municipal enterprise. The external brand did not translate into communicating the brand to other stakeholders, especially to patients and colleagues. The factory metaphor was applied to describe the working conditions and service provision and was in stark contrast to the brand slogans around taking better care of the patient.

It was the extensive focus on external branding and lack of internal branding that gave rise to the dilemma whereby the outward brand message was not communicated inwardly in an understandable way. The healthcare personnel relied on a fairly narrow idea of the municipal enterprise as a new organisational form. For the informants, having only the external brand to encapsulate the new 
organisational form created suspicion and scepticism, and they felt jeopardised the reliability of the services provided and challenged their own professional ethics and status.

The findings indicate that predictable dilemmas may lie ahead in the implementation of private-sector type economic and efficiency methods in public-sector healthcare organisations, which may demand innovative reconciliation. Given the sui generis nature of the private and public sectors (Olsen, 2010; Thynne, 2010; Lane, 2009, p. 8), and the fact that public-healthcare service provision is funded from taxation, it might be useful to give deeper consideration to the notion of customer service aimed at patients. Although the need for cost cutting and economic efficiency in public services applies to public healthcare, these organisations might benefit from adopting the customer focus from private-sector organisations and branding. In rebranding Finnish healthcare to convey it as business-like and customer focused, strong leadership, coordination across multiple functions, and stakeholder consent are clearly important, as suggested by Miller et al. (2014).

In line with dilemma theory, we attempted to reconcile the dilemmas we identified, and leant towards the literature on internal branding to do so. Healthcare professionals could be given more training to help them cope with new processes, and to develop new ways of working to better serve their customers, or patients, under the new organisational form and brand. They need tools that give patients the feeling that they are close, and will meet a human being who cares. Care professionals could also benefit from a better understanding of the economy and budgeting in their organisations. In their everyday choices they might then find opportunities to meet the needs of more patients than they did previously. Training on internal branding in the early stages of the branding and adoption process could foster the reconciliation of dilemmas by fostering brand understanding and internal brand buy-in (Miller et al. 2014).

It is also worth pointing out some specific features characterising the application of brand-management philosophy to trigger the adoption of new organisational forms within public-sector organisations. Managers and employees in public organisations adopt ideas about business tools from the external environment. Thus, ideas are translated into the organisation but it is important to be aware of the 
inherent nuanced differences between a public body and a private business (Czaniawska \& Sévon 1996; Bonnedahl \& Jensen 2007). As Lamb (1987) notes, in spite of the similarities in their approach to the market, public organisations remain different and these 'differences pose unique marketing problems that require unique marketing solutions' (p. 56). This resonates with Wæraas' (2008) argument that the often contradictory and inconsistent values and multiple identities characterising public organisations may hinder the symbolic consistency that organisational branding targets. These concerns are even more relevant given the role that employees play in public organisations. Another challenge related to branding in the public sector appears to be people restricting the meaning of the brand because they lack an understanding of branding and a strategic management perspective on it (Miller et al. 2014). Furthermore, the discursive institutional approach could be further developed in research on (health care) branding to examine how through discourses new ideas of (institutionalised) brands - such as health care - are developed, and how those new sets of ideas may bring in new values, rules and practices and ultimately legitimate those ideas (Schmidt, 2006; Peters, 2012).

One managerial implication that emerges is that healthcare organisations wishing to build a new brand should pay attention to both external and internal branding. Employees need comprehensive training in branding, and on the added value it could bring to their care work. The dilemma reconciliation process in this case would involve educating employees and CEOs at an early stage in the meaning of the brand message; that living the brand could mean providing better care to their patients. Branding activities in health care organisations are often considered to divert scarce resources from the primary focus of patient care. Branding is not in conflict with healthcare ethics when internal and external practices are intertwined, and when it is acknowledged that marketing in the public sector is a specific type of marketing. This assertion is in line with the findings of Gapp and Merrilees (2006) that internal branding is an effective long-term use of resources in health care organisations.

Both external and internal branding need to be worked on simultaneously if employees are to understand the full significance of the branding and its promise. If they are not able to live the brand, the external brand is at risk of being damaged, which in turn threatens its external and internal legitimacy. 
Branding should not be seen only as a name or slogan but as the sum of all the benefits that the brand offers (Gapp \& Merrilees, 2006).

Clearly the qualitative methodology applied here limits the generalizability of the research results and analysis. Nevertheless, it offers more potential in terms of extending the existing literature on internal branding and public-healthcare organisations than quantitative analysis, and thus of stimulating new discussion and identifying new research themes (Lee et al., 2007; Eisenhardt, 1989, p. 534).

Future research should focus on the vast range of public-healthcare organisations that have undergone organisational change, branding and rebranding, in order to enhance knowledge of the outcomes. Future studies could also benefit from the interdisciplinary approach whereby research from the fields of marketing and organisations is applied to make sense of the challenges and opportunities emerging in the healthcare sector. Moreover, a longitudinal study involving public-healthcare organisations and focusing specifically on internal branding would allow an assessment of its visibility in the outcomes of relevant change processes.

\section{Conclusions}

Theoretically, our unique contribution to health care branding comes first from applying the dilemma approach (Hampden-Turner and Trompenaars, 2000) and second from demonstrating how internal branding can reconcile dilemmas identified in the case organisations. Third, our research contributes to discursive institutionalism and to the knowledge of how branding ideas can be translated and transferred into public-healthcare sector organisations.

The results of the study indicate how a new organisational brand is understood through the external brand in the form in the form of logos and slogans and with an emphasis on economic efficiency. There were few signs of internal branding, however (Gotsi and Wilson, 2001; Hampden-Turner and Trompenaars, 2000; DiMaggio and Powell, 1983). Consequently, the employees were not fully able to 
specify the added value inherent in the municipal enterprise form. It therefore seems the strategic use of internal branding would enhance the internal and external legitimacy of branding.

\section{References}

Aaker, D. (1996), Building Strong Brands, Free Press, New York, NY.

Aaker, D.A. and Joachimsthaler, E. (2002), Brand Leadership, Simon \& Schuster UK Ltd, London.

Aurand, T.W., Gorchels, L. and Bishop, T.R. (2005), "Human resource management's role in internal branding: an opportunity for cross-functional brand message synergy", Journal of Product \& Brand Management, Vol. 14 No. 3, pp. 163-169.

Becher, T. and Trowler, P.R. (2001), Academic Tribes and Territories: Intellectual Enquiry and the Cultures, SHRE and Open University Press, Philadelphia, PA.

Berry, L.L. (2000), "Cultivating service brand equity", Journal of the Academy of Marketing Sciences, Vol. 28 No. 1, pp. 128-137.

Blumenthal, D. and Bergstrom, A.J. (2003), "Brand councils that care: towards the convergence of branding and corporate social responsibility", Journal of Brand Management, Vol. 10 No. 4, pp. 327341.

Bonnedahl, K. J. and Jensen, T. (2007), "Internationalization of the organizational field: Swedish grocery retailers in the European integration process". The International Review of Retail Distribution and Consumer Research, Vol. 17 No. 3, pp. 283-302.

Brookes, M. (2003), "Higher education: marketing in a quasi-commercial service industry", International Journal of Nonprofit and Voluntary Sector Marketing, Vol. 8 No. 2, pp. 134-142.

Caldwell, N. and Coshall, J. (2002), "Measuring brand associations for museums and galleries using repertory grid analysis", Management Decision, Vol. 40 No. 4, pp. 383-392.

Chapleo, C. (2010), "What defines "successful" university brands?", International Journal of Public Sector Management, Vol. 23 No. 2, pp. 169-183.

Chapleo, C. (2013), "Brand "infrastructure" in nonprofit organizations: challenges to successful brand building?”, Journal of Marketing Communications, http://dx.doi.org/10.1080/13527266.2012.741609.

Colyvas, J.A. and Powell, W.W. (2006), "Roads to institutionalization: the remark of boundaries between public and private science", Research of Organizational Behaviour, Vol. 27, pp. 305-353.

Czarniawska, B. and Sevón, G. (1996), Translating organizational change, Walter de Gruyter, New York.

Davies, G. (2008), "Employer branding and its influence on managers", European Journal of Marketing, Vol. 42 Nos 5/6, pp. 667-681.

de Chernatony, L. (1999), "Brand management through narrowing the gap between brand identity and brand reputation”, Journal of Marketing Management, Vol. 15 Nos 1/3, pp. 157-179. 
de Chernatony, L. and Dall'Olmo Riley, F. (1998), "Modelling the components of the brand", European Journal of Marketing, Vol. 32 Nos 11/12, pp. 1074-1090.

de Chernatony, L. and Harris, F. (2000), "Developing corporate brands through considering internal and external stakeholders", Corporate Reputation Review, Vol. 3 No. 3, pp. 268-274.

Deephouse, D.L. (1996), “Does isomorphism legitimate?”, Academy of Management Journal, Vol. 39 No. 4, pp. 1024-1039.

Devasagayam, R., Buff, C.L., Aurand, T.W., and Judson, K.M. (2010), "Brand building community membership within organizations: a viable internal branding alternative?", Journal of Product \& Brand Management, Vol. 19 No. 3, pp. 210-217.

DiMaggio, P.J., and Powell, W.W. (1983), "The iron cage revisited: institutional isomorphism and collective rationality in organizational fields", American Sociological Review, Vol. 48 No. 2, pp. 147160 .

Doyle, P. (1989), "Building successful brands: the strategic options", Journal of Consumer Marketing, Vol. 7 No. 2, pp. 5-20.

Eisenhardt, K.M. (1989), "Building theories from case study research", Academy of Management Review, Vol. 14 No. 4, pp. 532-550.

Eriksson, P. and Kovalainen, A. (2008), Qualitative Methods in Business Research, Sage Publications Ltd, London.

Forsander, A. (2004), "Social capital in the context of immigration and diversity: economic participation in the Nordic welfare states", Journal of International Migration and Integration, Vol. 5 No. 2, pp. 207227.

Foster, C., Punjaisri, K. and Cheng, R. (2010), "Exploring the relationship between corporate, internal and employer branding", Journal of Product \& Brand Management, Vol. 19 No. 6, pp. 401-409.

Gapp, R. and Merrilees, B. (2006), "Important factors to consider when using internal branding as a management strategy: a healthcare case study", Journal of Brand Management, Vol. 14 Nos 1/2, pp. $162-176$.

Ghose, K. (2009), "Internal brand equity defines customer experience", Direct Marketing: An International Journal, Vol. 3 No. 3, pp. 177-185.

Golden, A.A. and Geisler, C. (2007), "Work-life boundary management and the personal digital assistant”, Human Relations, Vol. 60 No. 3, pp. 519-551.

Gotsi, M. and Wilson, A. (2001), "Corporate reputation: seeking a definition", Corporate Communications: An International Journal, Vol. 6 No. 1, pp. 24-30.

Grant, D., Hardy, C., Oswick, C. and Putnam, L. (Eds) (2004), The SAGE Handbook of Organizational Discourse, The Cromwell Press Ltd, Great Britain.

Hampden-Turner, C. (1981), Maps of the Mind, Macmillan Publishing Company, New York, NY.

Hampden-Turner, C. (1990), Charting the Corporate Mind. From Dilemma to Strategy, Blackwell Publisher, Oxford. 
Hampden-Turner, C. (2009), Teaching Innovation and Entrepreneurship: Building on the Singapore Experiment, Cambridge University Press, New York, NY.

Hampden-Turner, C. and Trompenaars, F. (2000), Building Cross-Cultural Competence: How to Create Wealth from Conflicting Values, John Wiley \& Sons, Inc, New York, NY.

Handy, C. (1994), The Age of Paradox, Harvard Business School Press, Boston, MA.

Hankinson, G. (2001), "Location branding: a study of the branding practices of 12 English cities", Journal of Brand Management, Vol. 9 No. 2, pp. 127-142.

Harris, F. and de Chernatony, L. (2001), "Corporate branding and corporate brand performance", European Journal of Marketing, Vol. 35 Nos 3/4, pp. 441-456.

Hatch, M.J. and Schultz, M. (2003), "Bringing the corporation into corporate branding", European Journal of Marketing, Vol. 37 Nos 7/8, pp. 1041-1064.

Hudson, R. (2009), "Brand strategy for acute NHS trusts", Journal of Communication in Healthcare, Vol. 2(1), pp. 20-33.

Ind, N. (2001), Living the Brand, Kogan Page, London.

Jevons, C. (2006), "Universities: a prime example of branding gone wrong", Journal of Product and Brand Management, Vol. 15 No. 7, pp. 466-467.

Johansson, H. and Hvinden, B. (2007), "Re-activating the Nordic welfare states: do we find a distinct universalistic model?", International Journal of Sociology and Social Policy, Vol. 27 Nos 7/8, pp. 334346.

Jokinen, A., Juhila, K. and Suoninen, E. (Eds) (1999), Diskurssianalyysi liikkeessä [Discourse analysis on the move], Vastapaino, Jyväskylä.

Kallio, T. and Kuoppakangas, P. (2013), "Bandwagoning municipal enterprises: institutional isomorphism and the search for the Third Way", Policy Studies, Vol. 34 No. 1, pp. 19-35.

Kemp , E., Jillapalli ,R. and Becerra ,E. (2014), "Healthcare branding: developing emotionally based consumer brand relationships", Journal of Services Marketing, Vol. 28, No. 2, pp.126-137.

Kimpakorn, N. and Tocquer, G. (2009), "Service brand equity and employee brand commitment", Journal of Service Marketing, Vol. 24 No. 5, pp. 378-388.

Kotler, N. and Kotler, P. (1998), Museum Strategy and Marketing: Designing Missions, Building Audiences, Generating Revenue and Resources, Jossey-Bass, San Francisco, CA.

Kotler, P. and Levy, S.J. (1969), "Broadening the concept of marketing”, Journal of Marketing, Vol. 33 No. 1, pp. 10-15.

Kuoppakangas, P. (2014), “Adopting a municipal enterprise form: expectations and outcomes - three cases and dilemmas", Journal of Change Management, Vol. 14 No. 1, pp. 126-145.

Lamb, C. W. (1987), "Public sector marketing is different”, Business Horizons, Vol. 30 No. 4, pp. 5660. 
Lane, J-E. (2009), State Management: An Inquiry into Models of Public Administration and Management, Routledge, London.

Lee, B., Collier, P. M. and Cullen, J. (2007), "Reflections on the use of case studies in the accounting, management and organizational disciplines", Qualitative Research in Organizations and Management: An International Journal, Vol. 2 No. 3, pp. 169-178.

Louro, M.J. and Cunha, P.V. (2001), "Brand management paradigms", Journal of Marketing Management, Vol. 17 Nos 7/8, pp. 849-875.

Low, G. S. and Fullerton, R.A. (1994), "Brands, brand management, and the brand manager system: a critical-historical evaluation", Journal of Marketing Research, Vol. XXXI (May 1994), pp. 173-190.

Meyer, J. W. and Rowan, B. (1977), "Institutionalized organizations: Formal structure as myth and ceremony”, American Journal of Sociology, Vol. 83 No. 2, pp. 340-363.

Miles, S.J. and Mangold, G.Q. (2005), "Positioning Southwest Airlines through employee branding", Business Horizons, Vol. 48 No. 6, pp. 535-545.

Miller, D., Merrilees, B. and Yakimova, R. (2014), "Corporate rebranding: An integrative review of major enablers and barriers to the rebranding process", International Journal of Management Reviews, Vol. 16, pp. 265-289.

Mintzberg, H. (1989), Mintzberg on management: Inside our strange world of organizations, Free Press, New York.

Olsen, J.P. (2010), "Change and continuity: an institutional approach to institutions of democratic government", in Pierre, J. and Ingraham, P.W. (Eds), Comparative Administrative Change and Reform: Lessons Learned, McGill-Queen's University Press, Montreal and Kingston, pp. 15-47.

Peters, G. B. (2012), Institutional Theory in Political Science, The New Institutionalism, 3rd ed. The Continuum International Publishing Group, New York.

Pollitt, C. and Bouckaert, G. (2011), Public Management Reform: A Comparative Analysis - New Public Management, Governance, and the Neo-Weberian State, Oxford University Press, New York, NY.

Potter, J. and Wetherell, M. (1987), Discourse and Social Psychology - Beyond Attitudes and Behaviour, Sage Publications Ltd, London.

Punjaisri, K. and Wilson, A. (2007), "The role of internal branding in the delivery of employee brand promise", Brand Management, Vol. 15 No. 1, pp. 57-70.

Punjaisri, K. and Wilson, A. (2011), "Internal branding process: key mechanisms, outcomes and moderating factors”, European Journal of Marketing, Vol. 45 No. 9, pp. 1521-1537.

Punjaisri, K., Evanschitzky, H. and Wilson, A. (2009b), “Internal branding: an enabler of employees' brand-supporting behaviours”, Journal of Service Management, Vol. 20 No. 2, pp. 209-226.

Punjaisri, K., Wilson, A., and Evanschitzky, H. (2008), "Exploring the influences of internal branding on employees' brand promise delivery: implications for strengthening customer brand relationships", Journal of Relationship Marketing, Vol. 7 No. 4, pp. 407-424. 
Punjaisri, K., Wilson, A. and Evanschitzky, H. (2009a), "Internal branding to influence employees' brand promise delivery: a case study in Thailand", Journal of Service Management, Vol. 20 No. 5, pp. 561-579.

Quinn, R.E. (1988), Beyond Rational Management: Mastering the Paradoxes and Competing Demands of High Performance, Jossey-Bass, San Francisco, CA.

Sargeant, A. (2005), Marketing Management for Nonprofit Organizations, Oxford University Press, Oxford.

Schultz, D. and Barnes, B.E. (1999), Strategic Brand Communications Campaigns, NTC Business Books, Chicago, IL.

Schmidt, V. (2006), "Institutionalism", in Hay, C. and Lister, M and Marsh, D. (Eds.), The state: theories and issues, Palgrave Macmillan, Basingstoke, pp. 98-117.

Scott, W. R. (1983), "Health Care Organizations in the 1980s: The Convergence of Public and Professional Control Systems", in: Meyer, J. W. and Scott, R. W. (Eds.) Organizational environments: Rituals and rationality, Sage Publications, Beverly Hills, pp. 155-175.

Shank, G. (2002), Qualitative Research: A Personal Skills Approach, Merrill Prentice Hall, Upper Saddle River, NJ.

Silverman, D. (2000), Doing Qualitative Research, Sage Publications Ltd, London.

Simmons, J.A. (2009), ““Both sides now”: aligning external and internal branding for a socially responsible era", Marketing Intelligence \& Planning, Vol. 27 No. 5, pp. 681-697.

Smith, W.K. and Lewis, M.W. (2011), "Toward a theory of paradox: a dynamic equilibrium model of organizing", Academy of Management Review, Vol. 26 No. 2, pp. 381-403.

Storey, J. and Salaman, G. (2009), Managerial Dilemmas: Exploiting Paradox for Strategic Leadership, Wiley-Blackwell, Oxford.

Stride, H. and Lee, S. (2007), "No logo? No way: branding in the non-profit sector", Journal of Marketing Management, Vol. 23 Nos 1/2, pp. 1071-1022.

Suchman, M.C. (1995), "Managing legitimacy: strategic and institutional approaches", Academy of Management Review, Vol. 20 No. 3, pp. 571-610.

Suomi, K., Lemmetyinen, A. and Go, F. (2013), "The tension between a distinct brand identity and harmonisation - findings from Finnish higher education", Place Branding and Public Diplomacy, Vol. 9 No. 3, pp. 202-215.

Thynne, I. (2010), "Leaders and leadership in administrative reform", in Pierre, J. and Ingraham, P.W. (Eds), Comparative Administrative Change and Reform: Lessons Learned, McGill-Queen's University Press, Montreal and Kingston, pp. 68-87.

Vallaster, C. and de Chernatony, L. (2005), "Internationalisation of services brands: the role of leadership during the internal brand building process", Journal of Marketing Management, Vol. 21 Nos 1/2, pp. 181-203. 
Vallaster, C. and de Chernatony, L. (2006), "Internal brand building and structuration: the role of leadership”, European Journal of Marketing, Vol. 40 Nos. 7/8, pp. 761-784.

Wæraas, A. (2008), "Can public sector organizations be coherent corporate brands?", Marketing Theory, Vol. 8 No. 2, pp. 205-221.

Wæraas, A. and Solbakk, M.N. (2009), "Defining the essence of a university: lessons from higher education branding", Higher Education, Vol. 57 No. 4, pp. 449-462.

Wahl, A. (2007), "Labour and development: what can be learned from the Nordic model?", Labour, Capital and Society, Vol. 40 No. 2, pp. 81-105.

Whelan, S. and Wohlfeil, M. (2006), "Communicating brands through engagement with 'lived' experiences”, The Journal of Brand Management, Vol. 13 Nos. 4/5, pp. 313-329.

Yin, R.K. (2003), Case Study Research: Design and Methods, 8th ed, Sage Publications Inc, Newbury Park, CA.

\section{Notes}

[1] Due to the confidentiality agreement with the case organisations only one researcher had access to the data and therefore it was not possible to utilise researcher triangulation in the analysis. However, the researcher responsible for collecting and analysing the data discussed the findings and their potential interpretations on several occasions with the other researchers. 